\title{
Web Scraper Dan Graphql API Untuk Data Perguruan Tinggi Di Indonesia Berdasarkan Website Kementerian Ristekdikti
}

\section{(Studi Kasus: Website Kementerian Ristekdikti)}

\author{
Lingga Tiara, Hadi Syaputra, Widya Cholil \& A.Haidar Mirza \\ Fakultas Teknik Ilmu Komputer, Universitas Bina Darma \\ Email: linggatiara23@gmail.com
}

\begin{abstract}
The urge to obtain and transmit information is one of the reasons for current technological developments, such as the need for students to access higher education reporting forums or Forlap Dikti. Forlap Dikti is a website page developed by the Ministry of Research, Technology and Higher Education that contains data on student academic activities based on reporting data from universities in Indonesia. Therefore we need a support application to be able to facilitate and expedite the need for access to information on the Forlap Dikti website page using the android application. This study aims to: (1) Help collect student data as material for presenting the required information, (2) Design an application as a medium for finding information on student data at Bina Darma University, (3) With an efficient web scraping function it also helps in data analysis. This application uses puppeteer for scraping data from websites, App Inventor and GraphQL API to display student data.
\end{abstract}

Keywords: Graphql API, Scraper, Webserver, Web-Scraping, puppeteer

\section{Pendahuluan}

Internet memiliki keunggulan karena dapat menyediakan informasi yang mudah diakses. Terutama sebagai alat komunikasi yang lebih praktis. Dimana data yang diakses dari internet biasanya berupa halaman web yang berformat HTML (HyperText Markup language). Beberapa diantaranya berisi informasi bagi pengguna seperti tombol navigasi, penelusuran dan tata letak untuk memperindah, serta informasi lebih mudah dibaca. Salah satu pendorong perkembangan Internet adalah mesin pencari.

Mesin pencari secara teratur mengumpulkan informasi dari halaman website melalui bot yang menelusuri web. Mengambil informasi dari halaman web yang ada disebut "web scraping". Web scraping digunakan untuk mengambil sejumlah besar data dari halaman web, data yang diekstraksi disimpan dalam database dalam format tabel (spreadsheet). Dimana isu-isu yang dikutip dalam buletin pendidikan pada disitus berita online jpnn.com (diakses pada senin 7 februari 2021). Dalam berita online tersebut menyajikan berita peningkatan pemalsuan ijazah dan bagi universitas wajib untuk memastikan PIN (Penomoran Ijazah Nasional). Dikarenakan, jika seseorang dikatakan mahasiswa atau lulusan dan jika datanya tidak tercantum pada halaman Forlap maka keberadaan mahasiswa atau lulusan akan dicurigai.

Disini penulis menggunakan Web Scraper dan GraphQL untuk pendidikan dengan mengekstraksi data dari situs website Forum Pelaporan Perguruan Tinggi, juga dikenal sebagai Forlap Dikti yang biasa digunakan sebagai cara untuk memvalidasi data tentang aktivitas belajar mahasiswa, riwayat profil dosen dan informasi universitas yang ada di 
Indonesia. Forlap Dikti sangat penting bagi kelanjutan perguruan tinggi. Hal ini terlihat banyaknya mahasiswa yang mendaftar untuk penelitian, beasiswa, kontes maupun lulusan baru menggunakan semua data pada Forlap. Data akademik mahasiswa tersebut akan dijadikan acuan legalitas untuk data mahasiswa atau ijazah.

Forlap Dikti dapat diakses oleh seluruh lapisan masyarakat dengan mengakses web browser pada halaman (forlap.kemdikbud.go.id) yang dioperasikan oleh Pusat Data dan Informasi Iptek. Berdasarkan Surat Edaran Penerimaan dan kemahasiswaan No700/B/SE/2017 terkait penggunaan Ijazah Nasional, Forlap Dikti menyimpan data mahasiswa dari awal pendaftaran hingga penerbitan nomor seri Penomoran Ijazah Nasional (PIN) dan Sistem Verifikasi Ijazah secara Elektronik (SIVIL) pada 14 Desember 2017, Mahasiswa dan institusi pendidikan akan membutuhkannya dimasa depan. Namun dengan perkembangan teknologi yang semakin pesat, diperlukan terobosan-terobosan baru untuk mengirim dan menerima informasi dengan lebih cepat dan efisien. Kehadiran teknologi mobile semakin memudahkan mahasiswa dan institusi mencari informasi dan komunikasi baik secara verbal, non verbal maupun visual antara jarak dan waktu. Sistem operasi android digunakan sebagai pembaharuan teknologi informasi yang disesuaikan untuk memenuhi kebutuhan informasi suatu instansi. Dimana sering kali berkendala pada saat mengakses web yang membutuhkan Internet dan terkadang berkendala jika laman tersebut akan melakukan maintenance pada server.

Banyak penelitian telah dilakukan pada pengumpuam data dari situs web. Sebagai contoh (Riyadi, 2013) melakukan penelitian "Rancang Bangun REST Web Service untuk Perbandingan Harga Pengiriman dengan Metode Web Scrapping dan Pemanfaatan API". Pada penelitian ini dibuat aplikasi perbandingan biaya pengiriman TIKI, JNE dan POS Indonesia. Pengguna tidak perlu membuka situs masing-masing penyedia layanan pengiriman atau memasukkan data berulang kali. Pengembangan aplikasi dalam penelitian ini menggunakan teknologi web service REST, web scraping dan penggunaan API. Dalam penelitian ini penggunaan API digunakan untuk memperoleh data harga pengiriman dan harga jasa JNE express. Metode web scraping digunakan dalam penelitian ini untuk menentukan perbandingan harga pengiriman TIKI dan POS Indonesia. Setelah anda memiliki informasi pengiriman kemudian impor kedatabase. Layanan REST web service digunakan untuk mengakses data pengiriman dalam database. Selanjutnya penelitian yang lebih detail dilakukan oleh (Josi, 2014) dengan judul "Penerapan Teknik Web Scrapping pada Mesin Pencari Artikel Ilmiah". Aplikasi ini dibuat sebagai database web yang didistribusikan melalui web scraping pada aplikasi yang dibuat dan hasil dari pencarian disimpan dalam tabel menggunakan database MySQL.

Berdasarkan uraian pembahasan diatas, penulis akan mengeksplorasi, merancang dan mengimplementasi aplikasi web scraping pada platform Android. Aplikasi ini mengumpulkan data mahasiswa Univesitas Bina Darma Palembang dari situs Forlap Dikti yang tersimpan dalam database di web server dan membutuhkan android sebagai client untuk melihat data mahasiswa kampus tersebut melalui GraphQL API. Dengan menggunakan aplikasi ini, penulis ingin dengan mudah membantu mahasiswa maupun instansi yang menginginkan atau melihat data kegiatan akademik maupun sebagai legalitas data diri dan ijazah mahasiswa Universitas Bina Darma Palembang dengan lebih mudah. 


\section{Tinjauan Literatur}

Menurut Turland (dalam Josi, 2014) Web Scraping adalah teknik untuk memperoleh informasi dari website yang disalin secara otomatis tanpa harus menyalin secara manual. Tujuan dari web scraper adalah untuk mencari informasi dan kemudian dikumpulkan dalam situs web yang baru. Web scraping berfokus untuk mendapatkan data dengan cara mengambil dan mengekstrak data tersebut. Manfaat dari proses web scraping ialah agar informasi yang diekstraksi lebih terkonsetrasi sehingga membuat pencarian lebih mudah. Aplikasi web scraping berfokus pada cara mendapatkan data mengambil dan ekstrak data berdasarkan ukuran data bervariasi.

Proses web scraping dilakukan untuk mengambil data tertentu secara semi-terstruktur pada halaman web biasanya dalam bahasa markup seperti HTML atau XHTML. Selanjutnya proses akan memulai menganalisis data tersebut dan kemudian data yang dibutuhkan diambil untuk digunakan bagi kepentingan lain.

GraphQL merupakan suatu metode untuk mengakses API dengan menggunakan deskripsi data sesuai dengan permintaan pemakai yang mudah dipahami (https://graphql.org/). Ini merupakan bahasa yang bisa diajarkan pada pemakai aplikasi. Aplikasi ini kemudian dapat berkomunikasi dengan layanan backed. Selain itu, GraphQL juga dapat meminta data. GraphQL ini sama dengan JSON dimana sama-sama memiliki operasi untuk membaca kueri dan penulisan data. Buna (dalam Arief Permana sastra, 2020)

Selain itu, GraphQL memberi para pengelola API fleksibilitas untuk menambahkan atau menghambat permintaan yang sudah ada. Pengembang dapat membangun APIs dengan metode apapun yang mereka inginkan dan spesifikasi QraphQL akan memastikan mereka berfungsi dengan cara yang dapat diprediksi bagi klien (Antoni, Fikari \& Akbar, 2018; Antoni \& Akbar, 2019; Antoni, Jie \& Abareshi, 2020; Antoni, Herdiansyah, Akbar \& Sumitro, 2021).

Menurut Cahyo Widianarko (2018) Puppeteer merupakan node library yang menyediakan fungsi API untuk bisa mengontrol browser web chromium. Selain itu, Pupeteer dapat dikonfigurasi untuk menjalankan mode non-headless. Berikut cara menggunakan puppeteer sebagai berikut:

1. Melakukan Tangkapan layar dan PDF berdasarkan tampilan pada halaman website.

2. Menjelajahi sitis dalam SPA website untuk membuat prerendered content.

3. Melakukan Scraping pada situs website.

4. Mengotomatisasi element situs website, menjalankan pengujian UI testing dll

5. Merekam Runtime Performance Analysis untuk membantu mendiagnosis masalah dalam browser web.

Pada penelitian ini mengacu terhadap penelitian lain yang digunakan sebagai acuan referensi untuk mendukung penelitian yang akan diteliti. Penelitian mengenai pengambilan data dari website banyak dilakukan, Sebagai contoh (Riyadi, 2013) melakukan penelitian "Rancang Bangun REST Web Service untuk Perbandingan Harga Pengiriman dengan Metode Web Scrapping dan Pemanfaatan API". Pada penelitian ini dibuat aplikasi perbandingan biaya pengiriman TIKI, JNE dan POS Indonesia. Pengguna 
tidak perlu membuka situs masing-masing penyedia layanan pengiriman atau memasukkan data berulang kali. Pengembangan aplikasi dalam penelitian ini menggunakan teknologi web service REST, web scraping dan penggunaan API. Dalam penelitian ini penggunaan API digunakan untuk memperoleh data harga pengiriman dan harga jasa JNE express. Metode web scraping digunakan dalam penelitian ini untuk menentukan perbandingan harga pengiriman TIKI dan POS Indonesia. Setelah anda memiliki informasi pengiriman kemudian impor kedatabase. Layanan REST web service digunakan untuk mengakses data pengiriman dalam database. Selanjutnya penelitian dilakukan oleh (Josi, 2014) dengan judul "Penerapan Teknik Web Scrapping pada Mesin Pencari Artikel Ilmiah". Aplikasi ini dibuat sebagai database web yang didistribusikan melalui web scraping pada aplikasi yang dibuat dan hasil dari pencarian disimpan dalam tabel menggunakan database MySQL.

Penelitian lain mengenai metode ini dilakukan oleh B. Handaga (2019) forlap scraper menggunakan aplikasi android. Aplikasi ini merupakan aplikasi mobile berbasis android untuk sistem informasi yang memungkinkan menggunakan metode web scraping untuk mempermudah dan mempercepat dalam akses data pada website forlap ristekdikti menggunakan metode web scraping, android studio adalah bahasa pemograman java yang menggunakan IDE dan REST API untuk pertukaran data.

Dalam penelitian ini penulis juga mengacu pada penelitian dilakukan oleh Edy Santoso (2019) mengenai Pengambangan aplikasi lelang ternak burung Lovebird berbasis Android. Sistem pada aplikasi ini beroperasi dengan menggunakan platform android dan proses akuisisi data menggunakan query pada server yang tersedia untuk memudahkan proses akuisisi data. Aplikasi ini terhubung melalui server menggunakan GraphQL API, yang membentuk skema sesuai dengn kebutuhan sistem.

\section{Metode Penelitian}

\subsection{Metode Penelitian}

Berdasarkan pada permasalahan yang diteliti, metode yang digunakan dalam penelitian ini adalah metode deskriptif kualitatif (Fauzi, Dencik \& Asiati, 2019). Menurut Nana Syaodih Sukmadinata (2011: 73), Penelitian deskriptif kualitatif ditujukan untuk mendeskripsikan dan menggambarkan fenomena-fenomena yang ada, baik bersifat alamiah maupun rekayasa manusia, yang lebih memperhatikan mengenai karakteristik, kualitas, keterkaitan antar kegiatan.

\subsection{Metode Pengumpulan Data}

Adapun metode pengumpulan data yang dilakukan sebagai berikut:

\section{1) Studi Literatur}

Studi literatur dilakukan berdasarkan teori-teori yang mendukung penelitian dari berbagai referensi termasuk buku, paper atau jurnal penelitian, karya ilmiah, dan situs-situs penunjang lainnya untuk membantu dalammenyelesaikan tugas akhir terkait dengan materi penulisan skripsi ini.

\section{2) Observasi}

Tahap awal observasi yaitu pengumpulan data dengan melakukan suatu pengamatan secara langsung pada website kementrian ristekdikti yang akan menjadi objek penelitian. 
3) Dokumentasi

Dokumentasi bisa catatan maupun berupa foto selama proses penelitian berlangsung. Dokumentasi merupakan teknik pengumpulan data dengan menghimpun dan menganalisis baik dokumen tertulis, gambar maupun elektronik.(Nana Syaodih Sukmadinata, 2009: 221).

\subsection{Metode Pengembangan Aplikasi}

Metode pengembangan aplikasi yang digunakan pada penelitian ini menggunakan metode Rational Unified Process memiliki empat tahapan yaitu:

1) Inception, Tahap ini lebih pada memodelkan proses bisnis yang dibutuhkan (business modeling), mendefinisikan kebutuhan akan sistem yang akan dibuat (requirement) serta analisis dan desain.

2) Elaboration, Tahap ini lebih pada analisis dan desain sistem serta implementasi sistem yang fokus pada purwarupa sistem (prototype).

3) Construction, Tahap construction berfokus pada pengembangan komponen dan fiturfitur sistem. Melakukan implementasi dan pengujian sistem yang berfokus pada implementasi perangkat lunak pada kode program (coding).

4) Transition, Tahap transition lebih mengarah pada deployment atau instalasi sistem agar dapat dimengerti oleh pengguna. Aktivitas pada tahap ini termasuk pelatihan pengguna, pemeliharaan dan pengujian sistem apakah sudah memenuhi harapan pengguna.

\subsection{Analisis dan Perancangan}

\subsubsection{Inception}

Tahap ini lebih pada memodelkan proses bisnis yang dibutuhkan (business modelling) dan mendefinisikan kebutuhan akan disistem yang akan dibuat (requirement).

1) Bussiness Modelling

Business Modelling digunakan untuk menggambarkan model bisnis untuk meninjau, meningkatkan dan membuat sebuah bisnis. Model yang digunakan yaitu Business Process Model yang menggambarkan interaksi proses sistem tersebut dengan pihak luar. 


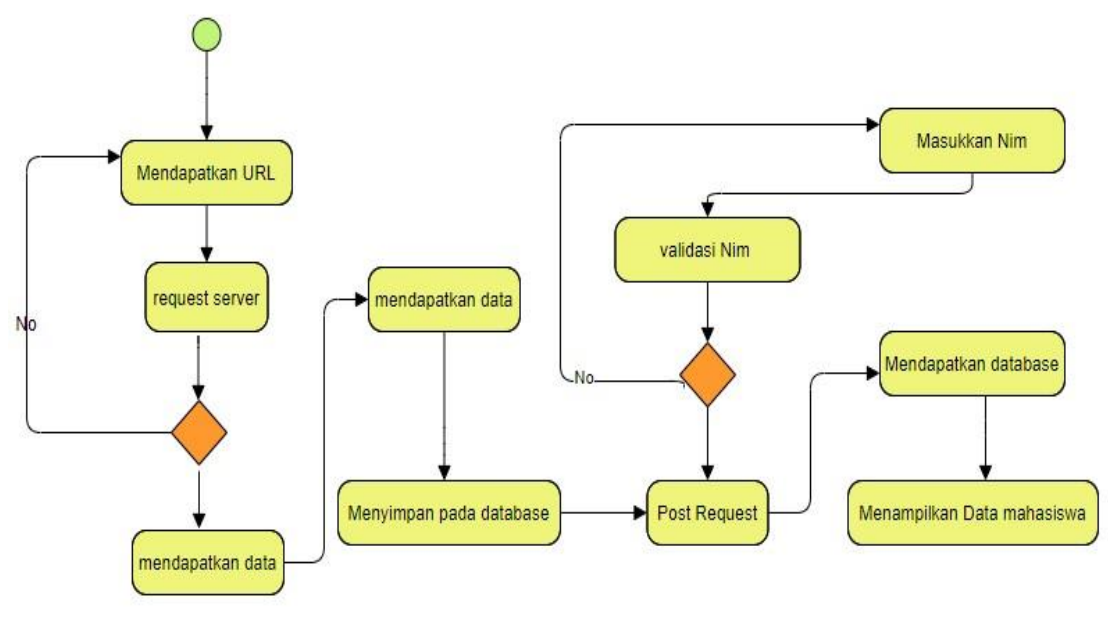

Gambar 1. Business Process Model

Proses ini diawali dengan mendapatkan alamat URL yang diinginkan atau target yang akan diambil informasinya. Setelah mendapat URL server melakukan request untuk mendapatkan data yang kita inginkan yang kemudian menyimpan data tersebut kedalam database. Pada android kita memasukkan nim kemudian server memvalidasi nim tersebut jika ada sesuai maka lanjut ke post request kemudian mendapatkan data kemudian melihat data tersebut, jika tidak ada maka akan kembali untuk memasukkan nim.

\section{2) Requirement}

Kegiatan yang dilakukan yaitu menganalisa kebutuhan fungsionalitas sesuai dengan aktor (pengguna). Kebutuhan fungsionalitas disusun berdasarkan pada hasil otomatisasi business case pada gambar 2 menunjukkan terdapat aktor yaitu user atau mahasiswa. Berikut kebutuhan fungsional yang berhasil diperoleh user dapat mengakses lima menu utama yaitu perguruan tinggi, program studi, mahasiswa, lihat peta dan lihat berita. dimana sistem ini berintegrasi pada sistem data mahasiswa Universitas Bina Darma. 


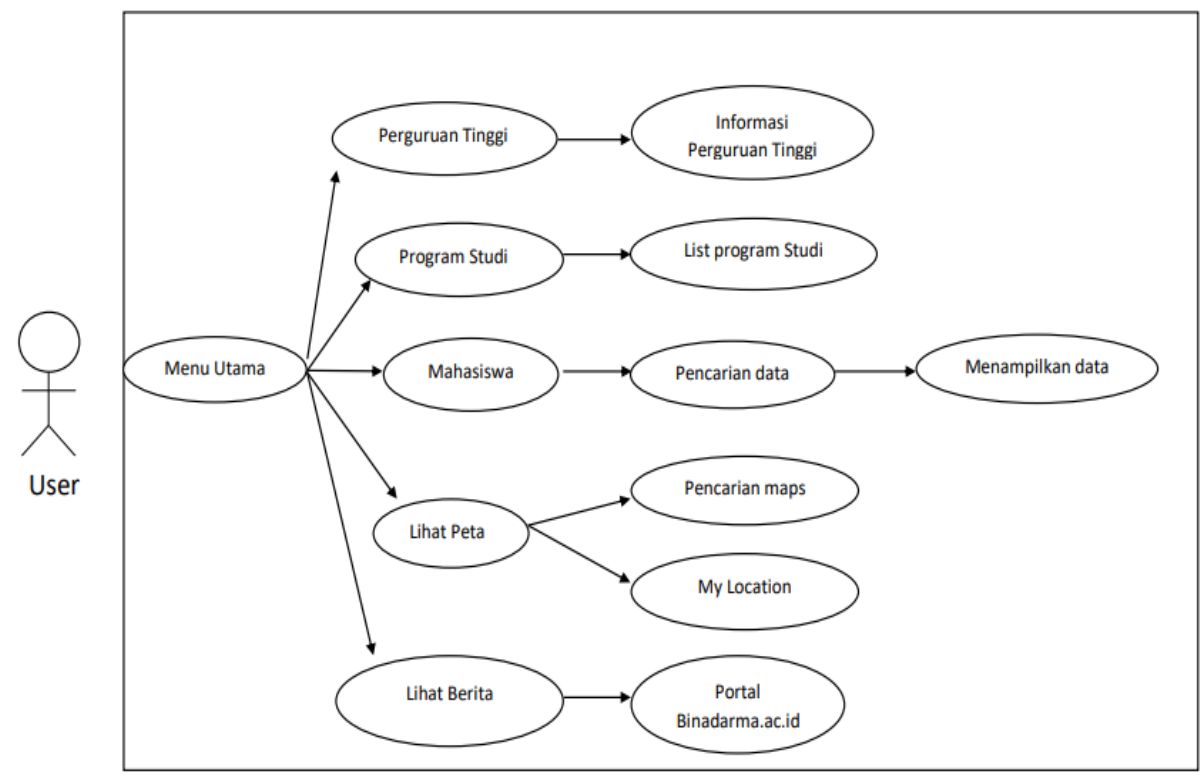

Gambar 2. Use Case Diagram

\subsubsection{Elaboration}

Berdasarkan proses bisnis pada tahap inception kemudian dilanjutkan pada tahap elaboration. Tahap ini lebih difokuskan pada perencanaan arsitektur sistem dengan menggunakan diagram UML yaitu diagram alir (flowchart), activity diagram, dan sequence diagram.

1) Analisis

Dari hasil penelitian yang dilakukan penulis dengan menggunakan aplikasi ini, penulis ingin membantu melihat data diri dan ijazah mahasiswa Universitas Bina Darma Palembang dengan lebih mudah dan efesien.

\section{2) Desain}

\section{a. Flowchart GraphQL API}

Pada gambar 3 flowchart GraphQL API menjelaskan alur dimulai dari client membuat schema yang dikoding berdasarkan data apa saja yang akan ditampilkan kemudian pada GraphQL request digunakan untuk mengetahui keyword yang akan kita gunakan untuk mencari data yang kita inginkan lalu pada server bisa melihat schema yang kita buat mulai dari nama, nim, jenis kelamin, kampus, jurusan, angkatan, status, tanggal lulus, ijazah dan jumlah sks, kemudian masukan ID Parameter data untuk mengetahui keyword suatu universitas yang ada di Indonesia, lalu parameter menerima data yang akan menuju link yang sudah ditentukan otomatis akan menuju halaman website forlap dikti yang berisi tentang data dari mahasiswa terkait. Mencari data kemudian akan tampil data dan kemudian di mengirimkan data respon tersebut kepada client. 


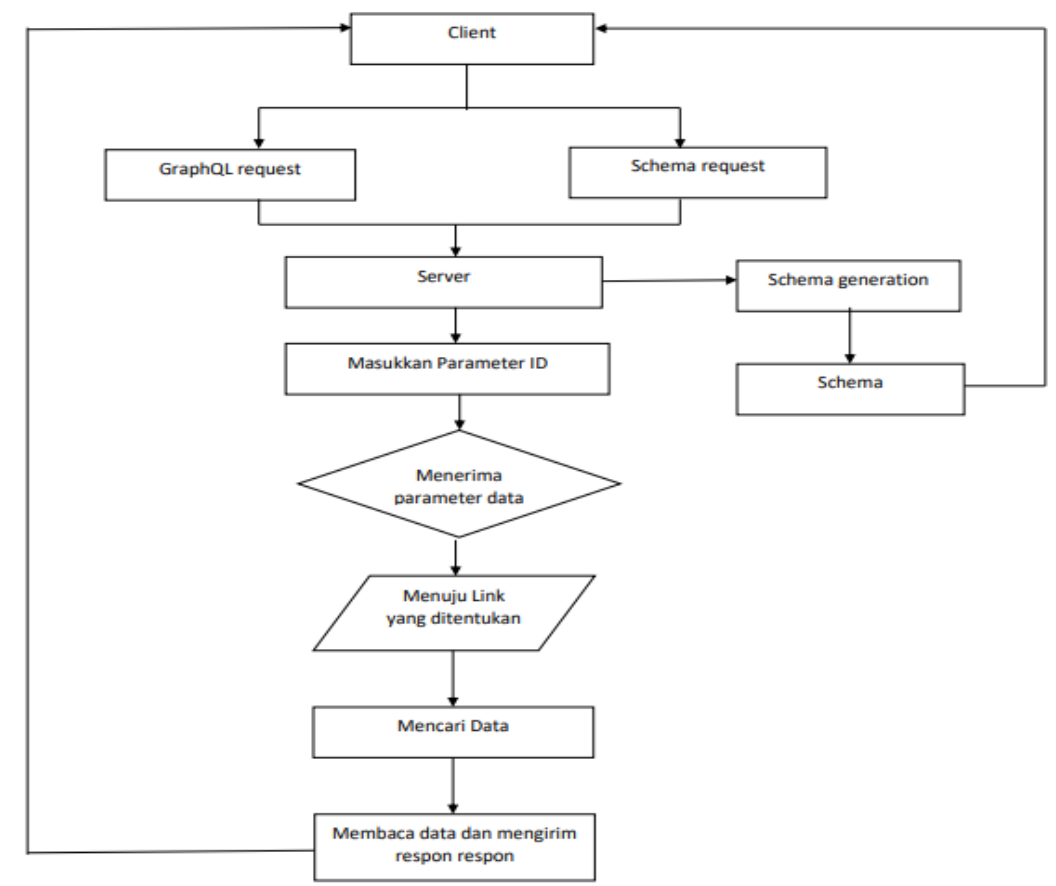

Gambar 3. Flowchart GraphQL API

\section{b. Diagram Activity}

Pada gambar 4 adalah diagram activity dalam pencarian data mahasiswa. Proses dimulai ketika pengguna masuk kedalam menu tampilan awal pada aplikasi kemudian menekan tombol mahasiswa selanjutnya memasukkan input nim mahasiswa yang diinginkan dan menekan tombol cek. Maka sistem akan melakukan pengecekan data. Jika data ada didatabase, Sistem akan menampilkan hasil pencarian. Jika tidak maka sistem akan menampilkan notifier data tidak ada cek kembali nim anda. 


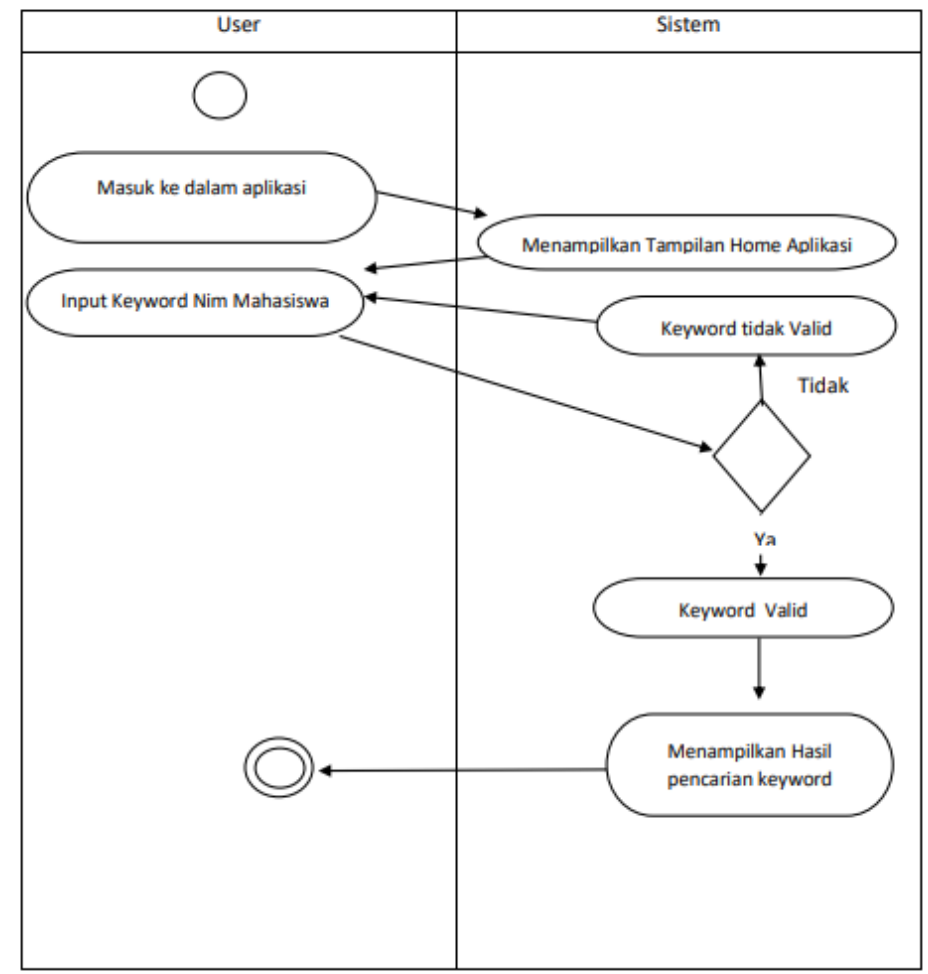

Gambar 4. Diagram Activity

3) Desain Struktur Menu

Perancangan antarmuka pengguna merupakan bagian penting dari proses desain aplikasi, karena ini berkaitan dengan tampilan dan interaksi antara pengguna dan aplikasi.

\section{a. Rancangan Tampilan SplashScreen}

Tampilan SplashScreen merupakan tampilan yang pertama muncul pada saat user akan aplikasi dijalankan. Tampilan ini terdiri dari screen yang memiliki background berupa gambar splashscreen. Pada tampilan splashscreen akan tampil selama 3 detik kemudian tampilan ini akan tertutup dan secara otomatis akan membuka tampilan menu utama. 


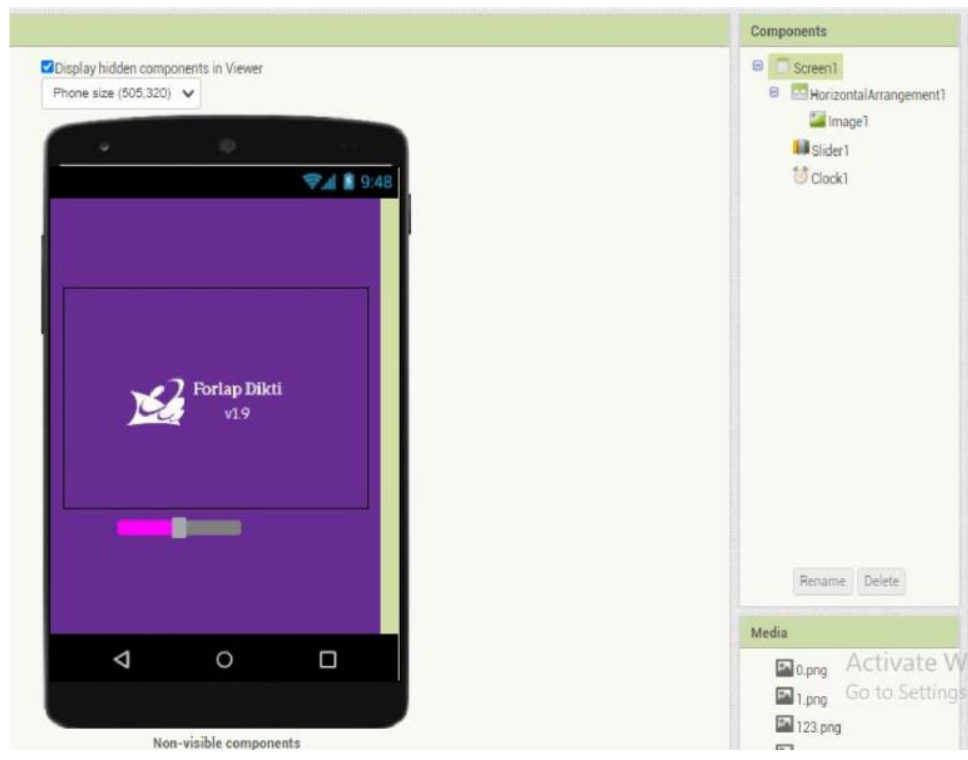

Gambar 5. Rancangan Tampilan SplashScreen

\section{b. Rancangan Menu Utama}

Pada tahap ini dilakukan pembangunan menu utama. Tampilan ini akan muncul pada saat user masuk kedalam sistem aplikasi. Pada tampilan menu utama berisi beberapa icon yang merupakan shortcut untuk membuka tampilan aplikasi yang lainya seperti berbagai fitur yang tersedia yaitu perguruan tinggi, program studi, mahasiswa, lihat peta serta lihat berita yang dapat dipilih oleh pengguna dengan mengklik button yang diinginkan. Berikut rancangan menu utama tersebut dapat dilihat pada gambar 3.8 dibawah ini

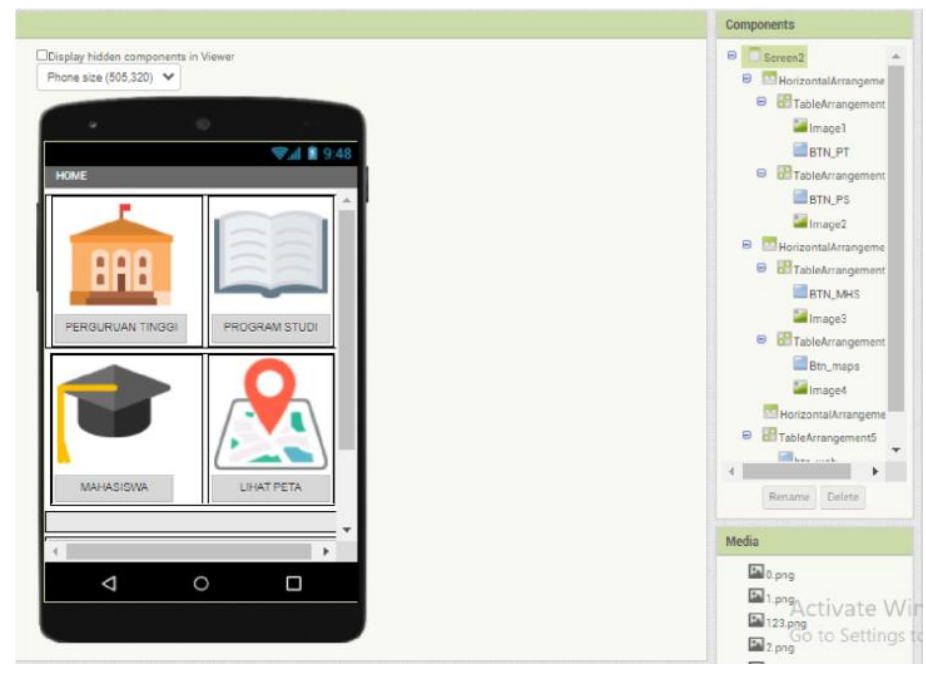

Gambar 6. Rancangan Menu Utama

c. Rancangan Menu Pencarian 
Menu pencarian mahasiswa akan memberikan informasi dan bagaimana pentingnya data mahasiswa untuk terdaftar didalamnya. Sedangkan button Pencarian Data akan menampilkan halaman form pencarian data, form tersebut terdiri dari field text input NIM dan dan button cek. User yang telah melakukan input pada form tersebut akan diproses melalui hosting web server dan akan ditampilkan data mahasiswa dari input yang telah dimasukkan oleh user.

Sedangkan pada button biodata mahasiswa yang terdiri 10 label akan menampikan informasi tentang nim, nama, gender, kampus, jurusan, angkatan, status, tanggal lulus, ijazah dan jumlah sks pada tampilan aplikasi tersebut. Berikut adalah rancangan interface dari menu pencarian mahasiswa ditunjukan pada gambar 3.11

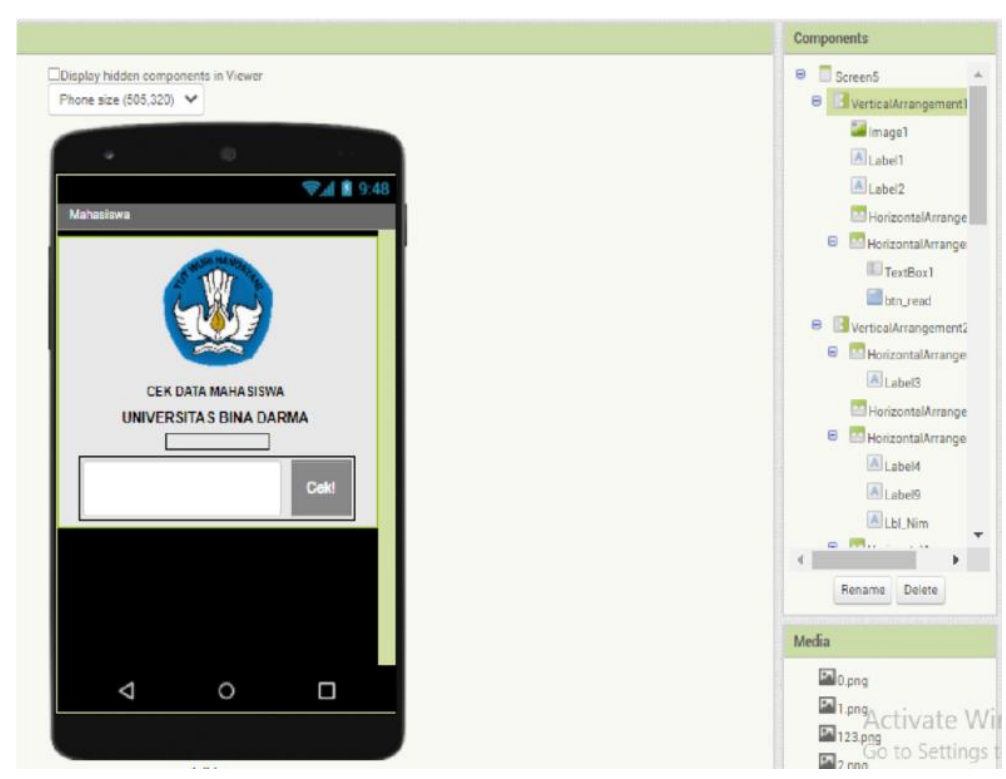

Gambar 7. Rancangan Menu Pencarian

d. Rancangan Hasil Biodata Mahasiswa

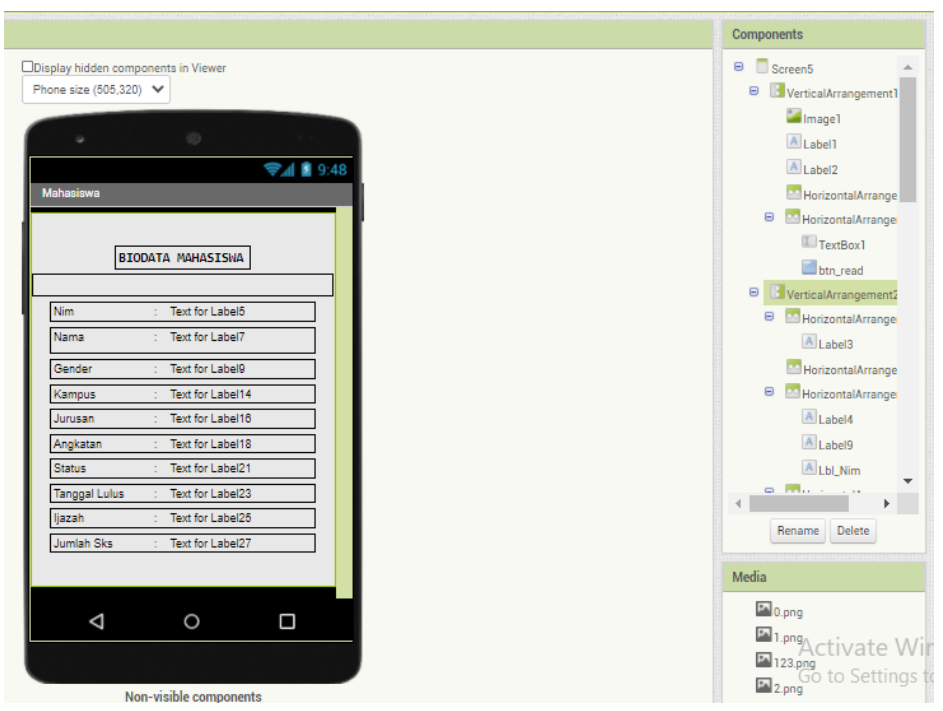

Gambar 8 Rancangan Hasil Pencarian

\section{Hasil dan Pembahasan}




\subsection{Construction}

\subsubsection{Implementation}

Metode yang digunakan adalah metode web scraping dengan menggunakan NodeJs. Proses ini dibagi menjadi beberapa langkah sederhana sebagai berikut:

1) Load HTML

Buat credentials untuk gsheet di GCP Console. Buat file dengan nama apisecret.json kemudian buat 1 file dokumen google spreadsheet, kemudian kasih akses penuh untuk client_email yang didapatkan dari credentials tadi. Copy credentials yang sudah dibuat tadi kedalam api-secret.json, untuk key spreadsheet_id bisa ditambahkan berdasarkan id spreadsheet yang dibuat.

Untuk membuat http server menggunakan Node.js, maka kita perlu mengimport module bawaan Node.js yang bernama http dan express, cara mengimport module adalah dengan mengetikkan kode program require ('namamodule') dan menaruhnya kedalam variabel atau konstanta, contohnya seperti const http = require('http') load module http maksud dari potongan kode program itu adalah kita memuat module http kedalam konstanta bernama http. Kemudian pada express framework ini merupakan pengembangan dari NodeJS yang bertugas untuk menangani kebutuhan dalam server-side.

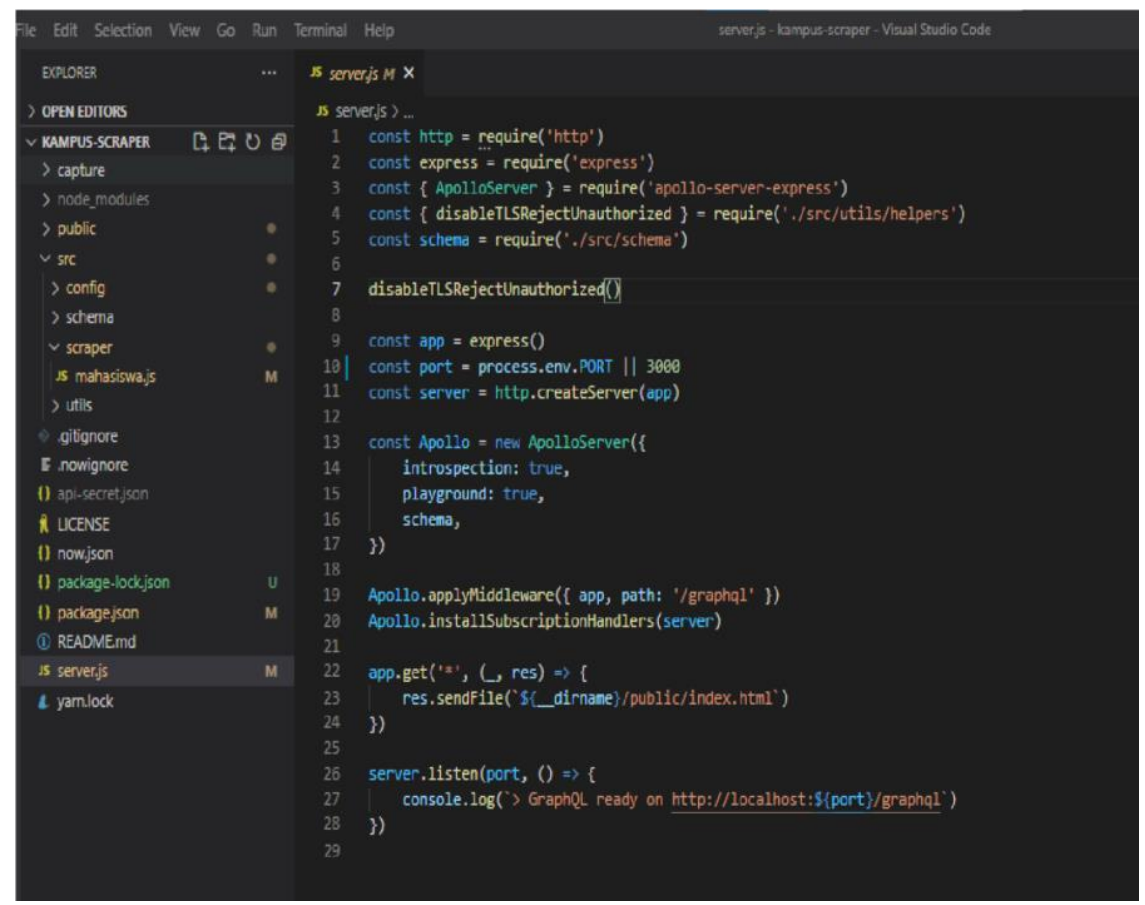

Gambar 9. Server.js

Setelah membuat HTTP Server kita juga harus menambahkan pada port beberapa backend kita akan mendengarkan dan akan memberikan respon, caranya adalah menambahkan listen (). Terakhir pada server.listen (port) akan dijalankan dan selalu dalam "mode stand-by" untuk mendapatkan request yang dikirim oleh user kita menjalankan HTTP Server pada port 3000 atau anda dapat mengakses server dengan mengetikkan pada web browser "http://localhost:3000".

2) Parsing HTML 
Setelah mendapatkan HTML dari request yang kita scraping lalu parsing untuk mengetahui keyword menggunakan Playground GraphQL API. Parameter kampusID bisa didapatkan dari request getListKampus (keyword) terlebih dahulu dari server GraphQL yang sudah dijalankan, contohnya dapat dilihat pada gambar berikut:

a. Query Get List Kampus

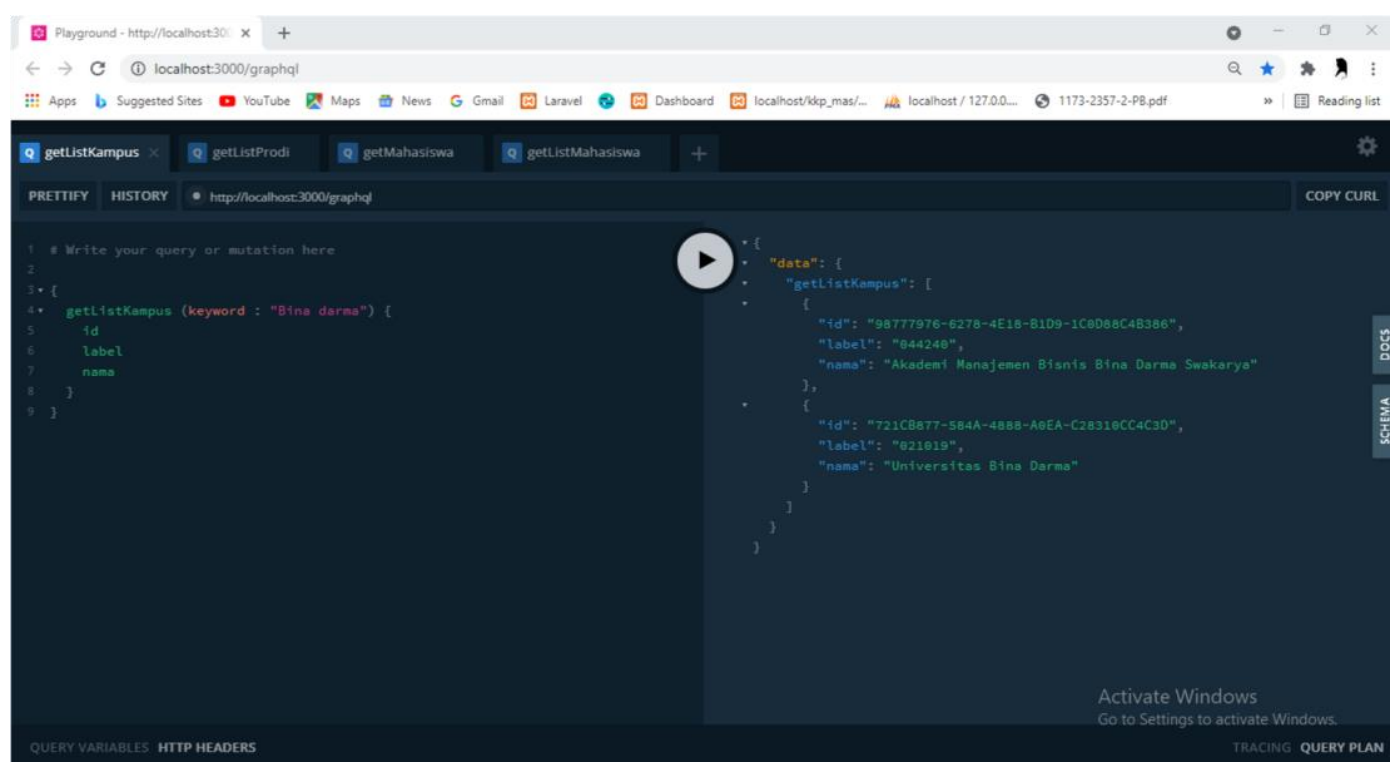

b. Query Get List Prodi

Gambar 10. Query Get List Kampus

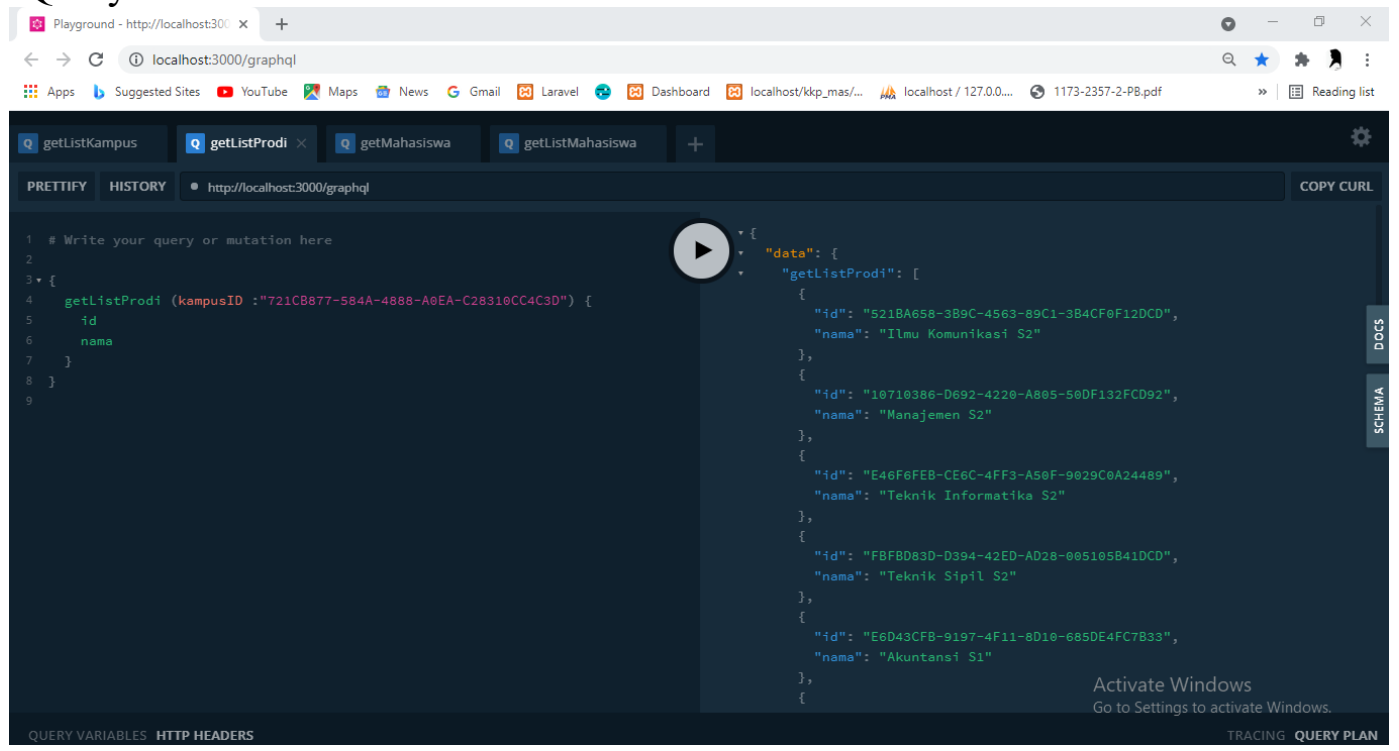

Gambar 11. Query Get List Prodi

c. Query Get Detail Mahasiswa 


\begin{tabular}{l|l|lr}
\hline & $N$ & $\begin{array}{l}\text { JURNAL } \\
\text { NASIONAL }\end{array}$ & $\begin{array}{r}\text { Jurnal Nasional Ilmu Komputer } \\
\text { e-ISSN: 2746-1343 }\end{array}$ \\
\hline & $\mathrm{K}$ & $\begin{array}{l}\text { ILMU } \\
\text { KOMPUTER }\end{array}$ & Vol. 2, No. 3, Agustus 2021 \\
\hline
\end{tabular}

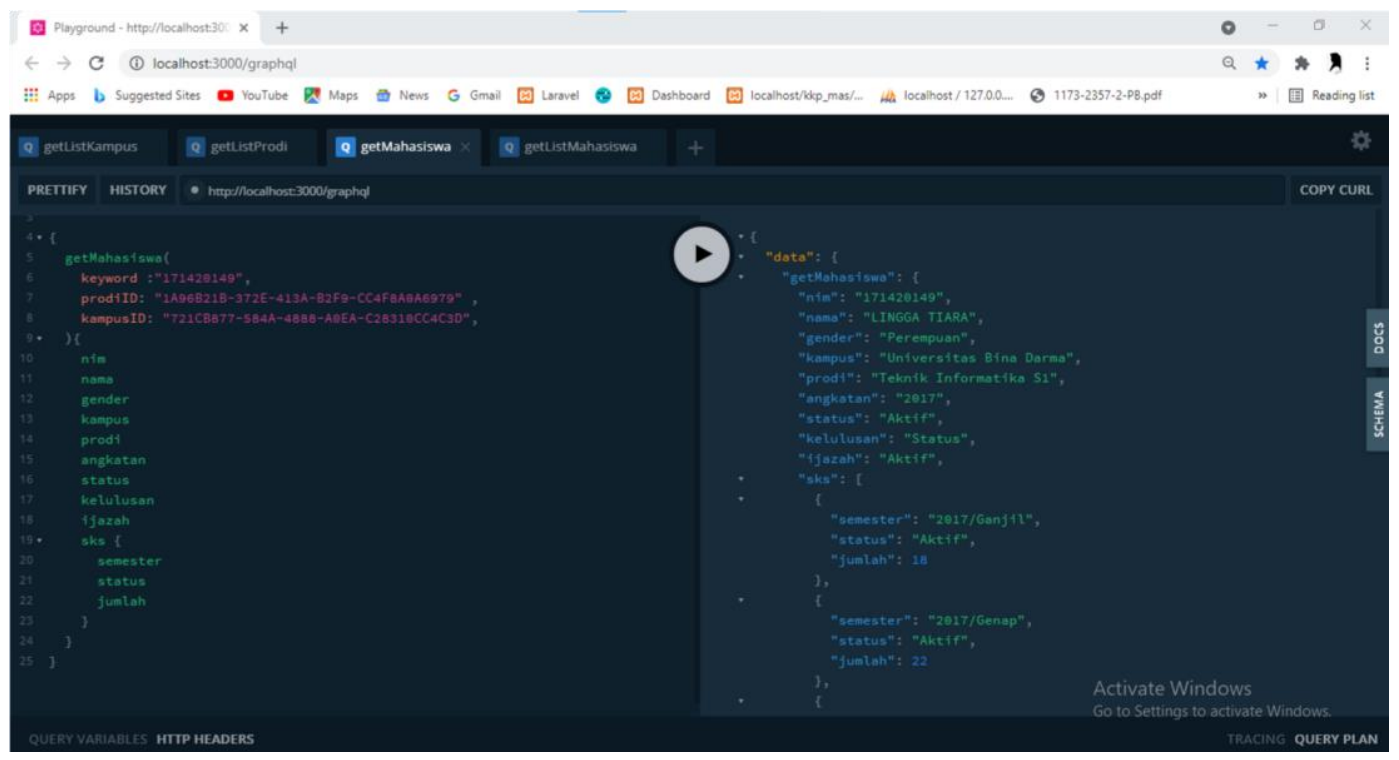

\section{3) Extract HTML}

Gambar 12. Query Get Detail Mahasiswa

Sebelum melakukan ekstraksi data yang dibutuhkan kita perlu untuk memeriksa struktur HTML dari halaman tersebut yang kita koding kemudian membuat schema dari data yang akan kita ambil dari page tersebut. Data tersebut dapat berupa tampilan yang akan muncul jika kita melakukan proses web scraping.

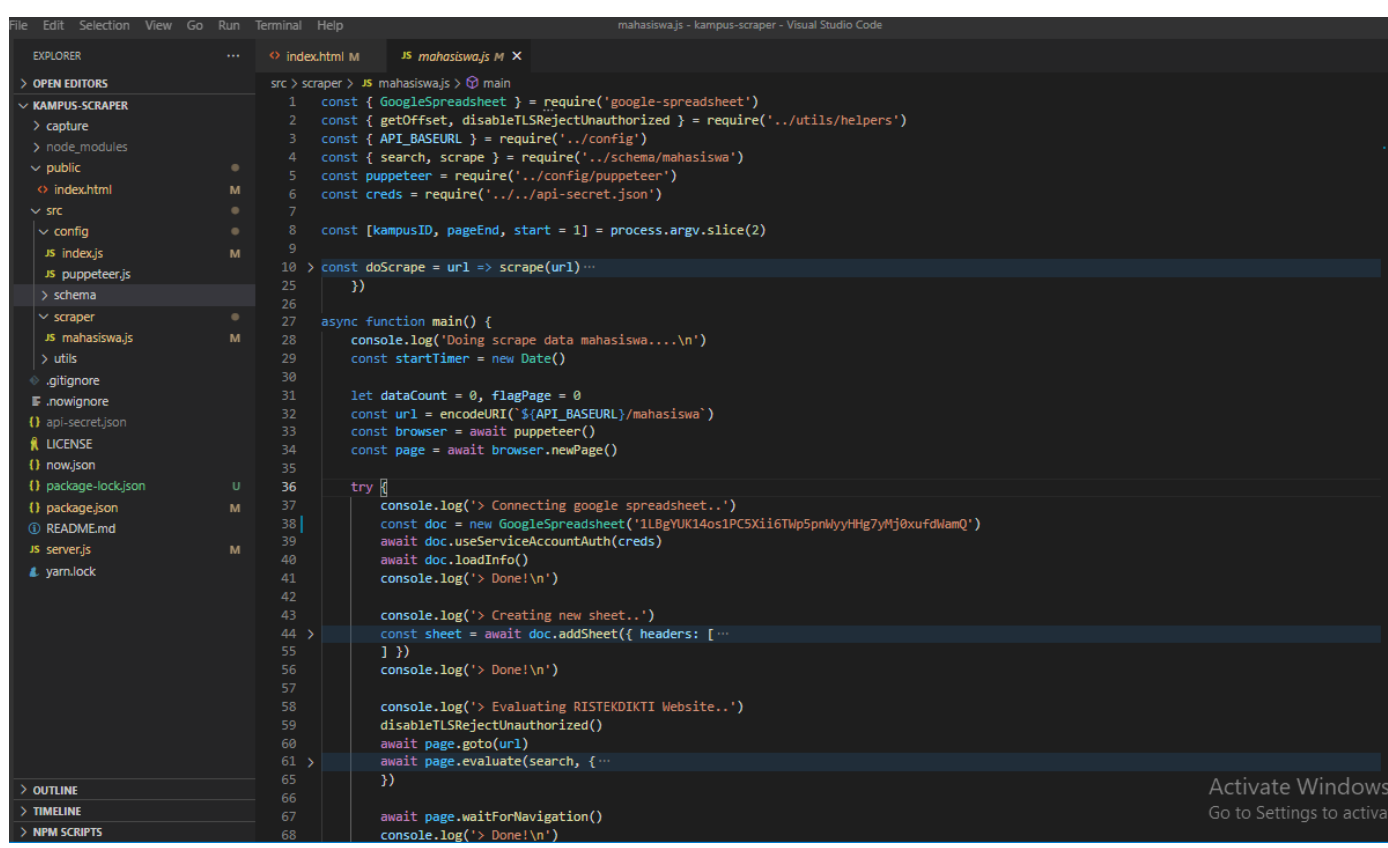

Gambar 13. Schema Mahasiswa

Jika sudah menemukan Keyword kemudian kita memulai collecting data dari target kampus dengan parameter KampusID yang didapatkan dari server GraphQL yang sudah dijalankan. Contoh query perintah menjalankan proses scraping: node src/scraper/mahasiswa.js \{kampusID\}\{batas_halaman\}\{start_halaman\}. 
Data diambil dari situs berdasarkan halaman page yang ada pada website. 1 halaman page berisi data 20 mahasiswa yang langsung terhubung kedalam database, data tersebut dimasukkan kedalam bentuk tabel spreadsheet berdasarkan nama tabel yang tertera. Data ini tidak akan membuat terjadi duplikat karena dilakukan proses scraping dengan per halaman.

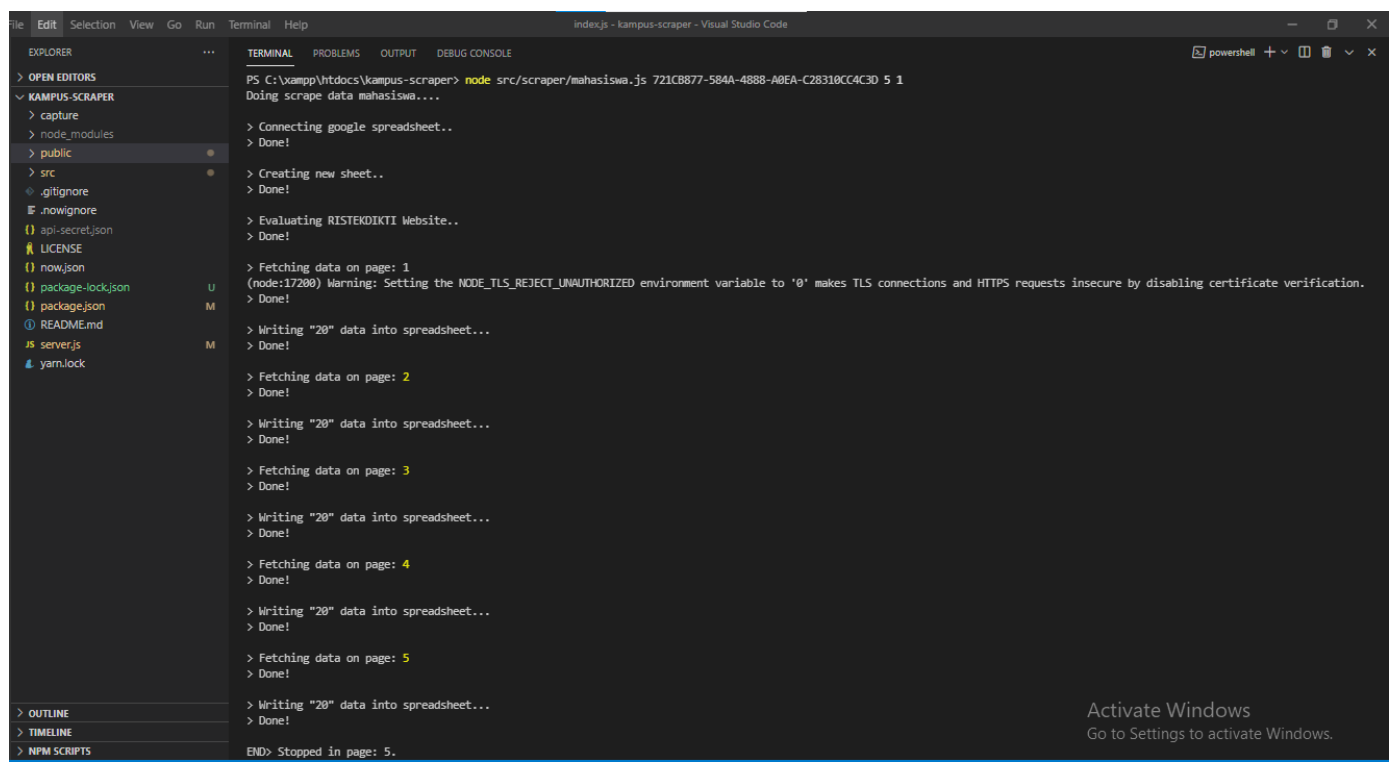

Gambar 14. query scraping

Berikut spreadsheet yang sudah collect ratusan ribu mahasiswa Universitas Bina Darma yang sudah dibuat melalui web scraping dapat dilihat pada link atau gambar berikut: (https://docs.google.com/spreadsheets/d/1LBgYUK14os1PC5Xii6TWp5pnWyyHHg7y Mj0xufdWamQ)

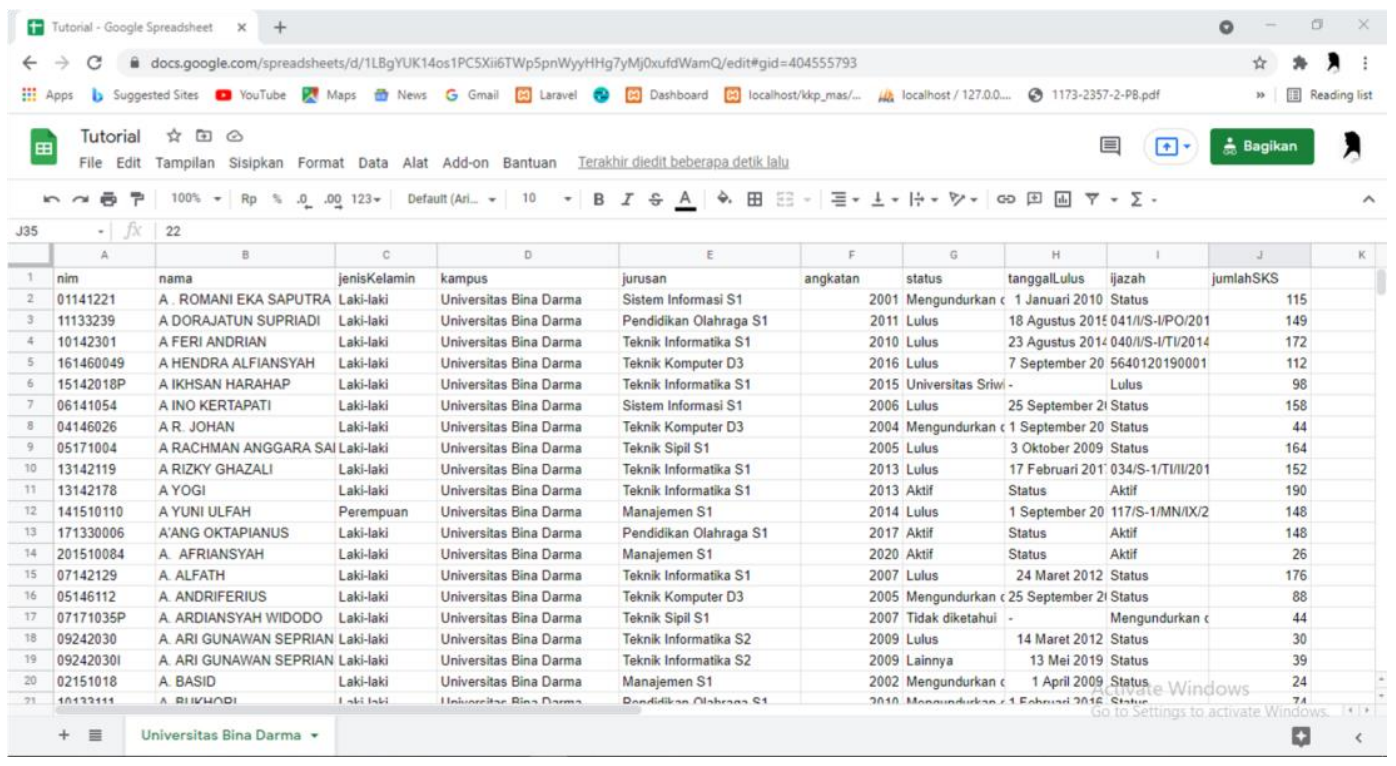

Gambar 15. Hasil Proses Web Scraping

\subsubsection{Tampilan Menu}

Published by: 
1) Tampilan SplashScreen

Aplikasi ini diawali dengan tampilan splashscreen ini muncul pada saat user akan membuka aplikasi yang akan menampilkan logo dari ristekdikti selama 3 detik kemudian tampilan ini akan tertutup dan secara otomatis akan membuka tampilan menu utama seperti pada gambar berikut:

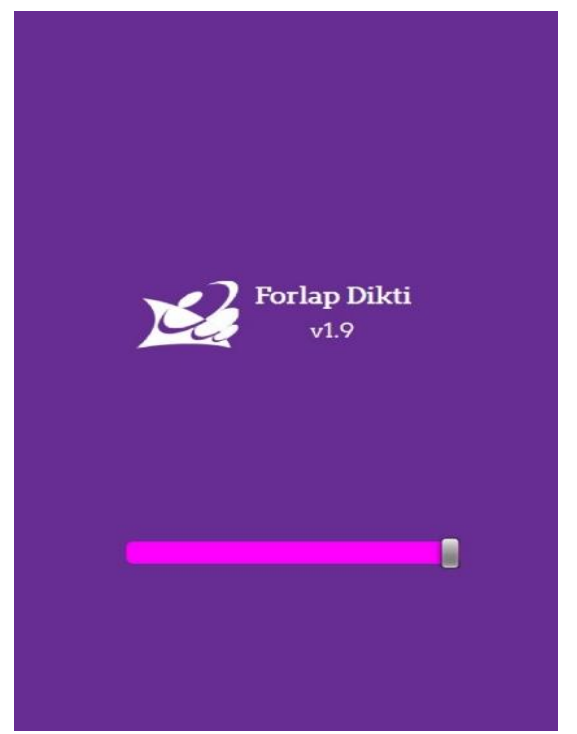

Gambar 16. Tampilan SplashScreen

2) Tampilan Menu Utama

Tampilan ini akan muncul pada saat user masuk kedalam sistem aplikasi. Apliksi ini akan menampilkan lima button yang dapat diakses user seperti berbagai fitur yang tersedia yaitu perguruan tinggi, program studi, mahasiswa, lihat peta serta lihat berita yang dapat dipilih oleh pengguna dengan mengklik button yang diinginkan. Tampilan menu utama dapat dilihat pada gambar berikut:

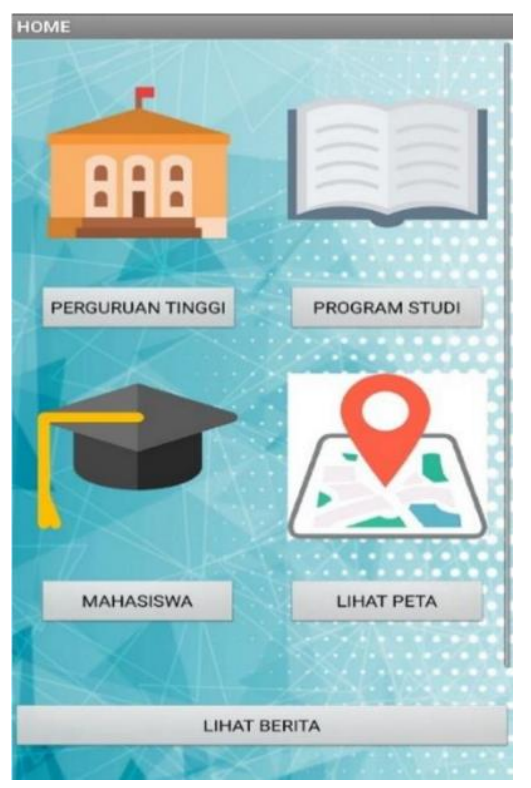

Gambar 17. Tampilan Menu Utama

Pada Gambar diatas menampilkan tampilan menu pencarian data mahasiswa, formulir ini 
berisikan field text input NIM dan dan button cek. Pengguna dapat menggunakan kata kunci (keyword) untuk melakukan pencarian data yang diinginkan pada kotak teks yang ada pada menu pencarian.

\section{3) Tampilan Pencarian Data Mahasiswa}

Menu pencarian mahasiswa akan memberikan informasi dan bagaimana pentingnya data mahasiswa untuk terdaftar didalamnya. Sedangkan button Pencarian Data akan menampilkan halaman form pencarian data, form tersebut terdiri dari field text input NIM dan dan button cek. User yang telah melakukan input pada form tersebut akan diproses melalui hosting web server dan akan ditampilkan data mahasiswa dari input yang telah dimasukkan oleh user.

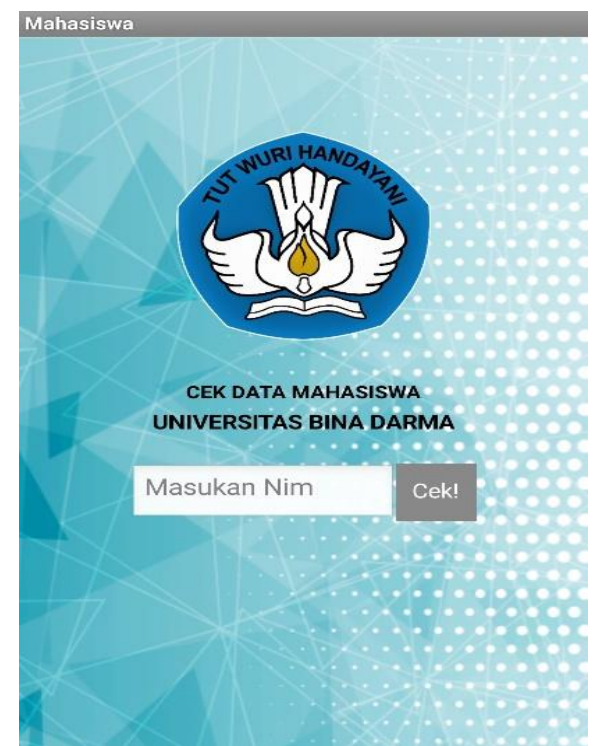

Gambar 18. Tampilan Form Pencarian mahasiswa

Pada gambar diatas menampilkan tampilan menu pencarian data mahasiswa, formulir ini berisikan field text input NIM dan dan button cek. Pengguna dapat menggunakan kata kunci (keyword) untuk melakukan pencarian data yang diinginkan pada kotak teks yang ada pada menu pencarian.

\section{4) Tampilan Hasil Biodata Mahasiswa}

Pada gambar 4.7 merupakan hasil proses dari inputan keyword berupa nim pengguna pada formulir pencarian mahasiswa kemudian akan diproses dan akan ditampilkan data mahasiswa yang diinputkan oleh pengguna, kemudian akan menampikan informasi yang berisikan tentang nim, nama, gender, kampus, jurusan, angkatan, status, tanggal lulus, ijazah dan jumlah sks pada tampilan aplikasi tersebut dapat dilihat pada gambar berikut ini: 


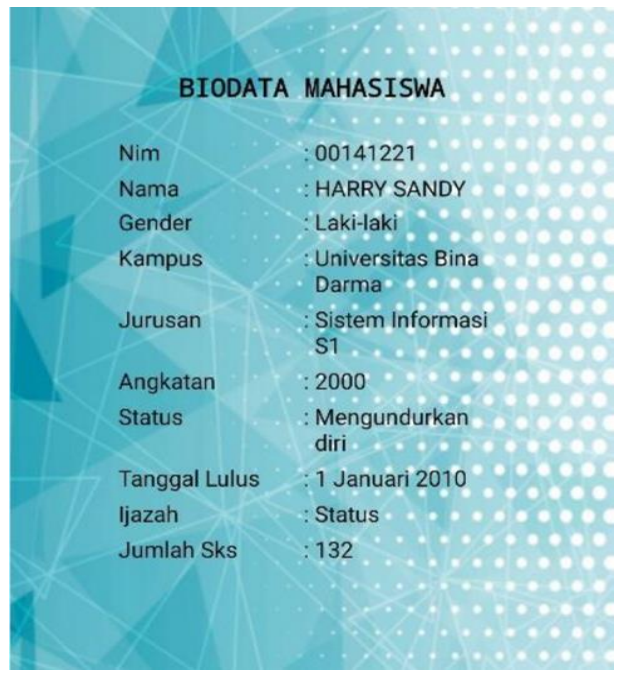

Gambar 19. Hasil Pencarian Mahasiswa

\subsection{Transition}

Pengujian sistem merupakan bagian penting dari proses pengembangan perangkat lunak. Pengujian dilakukan untuk memastikan kualitas dan mendeteksi kelemahan perangkat lunak. Tujuan dari pengujian ini adalah untuk memastikan bahwa perangkat lunak yang berkualitas tinggi dan berjalan dengan benar seperti yang diharapkan atau tidak. Hasil pengujian dapat ditunjukkan pada tabel berikut:

Tabel 1. Hasil Pengujian Black Box Testing

\begin{tabular}{|l|l|l|l|}
\hline \multicolumn{1}{|c|}{ Button } & \multicolumn{1}{|c|}{ Test } & \multicolumn{1}{|c|}{ Hasil } & Kesimpulan \\
\hline Perguruan Tinggi & $\begin{array}{l}\text { Mengklik menu } \\
\text { Perguruan Tinggi }\end{array}$ & $\begin{array}{l}\text { Menampilkan informasi atau } \\
\text { pengenalan tentang PT }\end{array}$ & Valid \\
\hline Program Studi & $\begin{array}{l}\text { Mengklik menu } \\
\text { Program Studi }\end{array}$ & $\begin{array}{l}\text { Menampilkan list program studi } \\
\text { yang ada di PT }\end{array}$ & Valid \\
\hline Mahasiswa & $\begin{array}{l}\text { Mengklik menu } \\
\text { pencarian data }\end{array}$ & $\begin{array}{l}\text { Menampilkan pencarian form } \\
\text { data }\end{array}$ & Valid \\
\hline $\begin{array}{l}\text { Mengisi form } \\
\text { pencarian data }\end{array}$ & $\begin{array}{l}\text { Menampilkan pencarian hasil } \\
\text { data }\end{array}$ & Valid \\
\hline Maps & $\begin{array}{l}\text { Mengklik menu } \\
\text { view map }\end{array}$ & $\begin{array}{l}\text { Menampilkan form address } \\
\text { yang terintegrasi ke google maps }\end{array}$ & Valid \\
\cline { 2 - 4 } & $\begin{array}{l}\text { Mengklik menu My } \\
\text { Location }\end{array}$ & $\begin{array}{l}\text { Menampilkan form address } \\
\text { yang terintegrasi ke lokasi awal }\end{array}$ & Valid \\
\hline Lihat Berita & $\begin{array}{l}\text { Mengklik menu } \\
\text { Bina Darma }\end{array}$ & $\begin{array}{l}\text { Menampilkan integrasi ke link } \\
\text { binadarma.ac.id }\end{array}$ & Valid \\
\hline
\end{tabular}

\section{Kesimpulan}

Berdasarkan hasil implementasi aplikasi web scraping ini menggunakan sistem mobile android dengan metode web scraping, maka disini penulis dapat menarik beberapa kesimpulan sebagai berikut:

1. Berdasarkan kesimpulan data aplikasi yang dihasilkan dengan menerapkan teknik web scraping untuk mengekstrak informasi berupa data mahasiswa dari website kementrian ristekdikti berhasil dilakukan. 
2. Aplikasi ini berhasil menyimpan otomatis data hasil dari ekstrak data kedalam database bentuk tabel spreadsheet.

3. Hasil pencarian informasi mahasiswa tersebut sesuai dengan keyword yang dimasukkan. Tidak hanya itu aplikasi ini juga bermanfaat untuk manampilkan sejumlah informasi mengenai universitas bina darma Palembang.

\section{Referensi}

Antoni, D., Herdiansyah, M. I., Akbar, M., \& Sumitro, A. (2021). Pengembangan Infrastruktur Jaringan Untuk Meningkatkan Pelayanan Publik di Kota Palembang. JURNAL MEDIA INFORMATIKA BUDIDARMA, 5(4), 1652-1659.

Antoni, D., Jie, F., \& Abareshi, A. (2020). Critical factors in information technology capability for enhancing firm's environmental performance: case of Indonesian ICT sector. International Journal of Agile Systems and Management, 13(2), 159-181.

Antoni, D., \& Akbar, M. (2019). E-supply chain management value concept for the palm oil industry. Jurnal Sistem Informasi, 15(2), 15-29.

Antoni, D., Fikari, D., \& Akbar, M. (2018). The readiness of palm oil industry in enterprise resource planning. Telkomnika, 16(6), 2692-2702.

Fauzi, F., Dencik, A. B., \& Asiati, D. I. (2019). Metodologi Penelitian untuk manajemen dan akuntansi. Jakarta: Salemba Empat.

Riyadi. 2013. Rancang Bangun REST Web Service untuk Perbandingan Harga Pengiriman dengan Metode Web Scrapping dan Pemanfaatan API. Yogyakarta: Sekolah Tinggi Manajemen Informatika dan Komputer Amikom Yogyakarta

Josi, Ahmat, and Leon Andretti Abdillah. "PENERAPAN TEKNIK WEB SCRAPING PADA MESIN PENCARI ARTIKEL ILMIAH," n.d., 6.

Prayitno Agus, Yulia safitri. 2015. Pemanfaatan Sistem Informasi Perpustakaan

Digital Berbasis Website Untuk Para Penulis. Volume 1 No.1. Jakarta timur: AMIKBSI

Sukmadinata, Nana Syaodih. 2009. Metode Penelitian Pendidikan. Bandung: PT. Remaja Rosdakarya.

H. Hesti. 2020. Rancang bangun aplikasi pelaporan kecelakaan lalu lintas berbasis online di Polres Kota Palopo. Skripsi thesis, UNIVERSITAS COKROAMINOTO PALOPO.

Sastra, Arief Permana. (2020) ANALISIS PERBANDINGAN METODE GRAPHQL DAN METODE REST API PADA TEKNOLOGI NODEJS. Skripsi thesis, STMIK

C, widianarko. (2018). Studi Perbandingan website view framework (vue js) dengan vanilla js. Yogyakarta: STMIK AKAKOM

A.S Rosa dan Salahuddin M, 2011. Modul Pembelajaran Rekayasa Perangkat Lunak (Terstruktur dan Berorientasi Objek), Modula, Bandung.

\section{Copyrights}

Copyright for this article is retained by the author(s), with first publication rights granted to the journal. 
This is an open-access article distributed under the terms and conditions of the Creative Commons Attribution license (http://creativecommons.org/licenses/by/4.0/) 